\title{
Effects of diabetes and hypoxia on gene markers of angiogenesis (HGF, cMET, uPA and UPAR, TGF- $\alpha$, TGF- $\beta$, bFGF and Vimentin) in cultured and transplanted rat islets
}

\author{
B. Vasir, P. Reitz, G.Xu, A.Sharma, S. Bonner-Weir, G. C. Weir
}

Section on Islet Transplantation and Cell Biology, Research Division, Joslin Diabetes Center and Department of Medicine, Harvard Medical School, Boston, Massachusetts, USA

\section{Abstract}

Aims/hypothesis. The vascularisation of newly transplanted islets originates from the recipients. Because islets transplanted into a diabetic do less well than those transplanted into a euglycaemic environment, we examined the hypothesis that gene expression of angiogenic factors in grafts is delayed in diabetes. These factors include hepatocyte growth factor (HGF) and its receptor c-MET, and urokinase plasminogen activator ( $\mathrm{UPA}$ ) and its receptor UPAR, basic fibroblast growth factor (bFGF), TGF- $\alpha$ and TGF $\beta-1$. Methods. Isolated rat islets were studied in vitro under normoxic and hypoxic culture conditions and gene expression was determined with semi-quantitative multiplex RT-PCR. We found that HGF but not c-MET expression was induced by hypoxia in vitro. Using syngeneic Lewis rats, gene expression was also studied in grafts on days $1,3,5,7$ and 14 after transplantation.

Results. In grafts of normoglycaemic rats, HGF expression was enhanced on day 3 and maintained whereas expression of c-MET fell and remained down until day 14. Expression of uPA was up at day 3 and remained high; expression of UPAR was also up at day 3 but then fell to control levels at day 14 . Expression of bFGF, TGF- $\alpha$ and TGF $\beta-1$ persisted throughout. Vimentin, a marker of fibroblasts, had increased expression at day 1 which was further enhanced in subsequent days. In the grafts of diabetic recipients the expression of HGF, uPA and UPAR were delayed, being clearly expressed at day 5 rather than day 3. Vimentin expression was similarly delayed.

Conclusion/interpretation. This apparent delay in angiogenesis provides a potential mechanism for the less favourable outcomes of islets transplanted into diabetic recipients. [Diabetologia (2000) 43: 763-772]

Keywords Diabetes, islet transplantation, angiogenesis, hepatocyte growth factor and c-MET receptor and urokinase plasminogen activator, $\mathrm{bFGF}$, TGF- $\beta$, TGF- $\alpha$.
Vascularisation of transplanted islets is largely established over a 10-day period, with the angiogenesis be-

Received: 11 January 2000 and in revised form: 24 February 2000

Corresponding author: G. C. Weir MD, Section of Islet Transplantation and Cell Biology, Joslin Diabetes Center, One Joslin Place, Boston, MA 02215, USA

Abbreviations: VEGF, Vascular endothelial growth factor; bFGF, basic fibroblast growth factor; PDGF, platelet-derived growth factor; HGF, hepatocyte growth factor; TBP, TATAbox-binding protein; uPA, urokinase plasminogen activator; $\mathrm{SD}$, Sprague-Dawley; IE, islet equivalents. ing mostly derived from recipient precursor elements [1]. This rapid development of blood vessels facilitates the delivery of oxygen and nutrients to the grafts, thereby being critical for optimising insulin production. Several studies indicate that islets transplanted into the diabetic milieu do less well than those placed into a normoglycaemic environment [2-4]. This study explores the hypothesis that the diabetic state interferes with the vascularisation of transplanted islets.

The initiation of angiogenesis is presumed to be in part due to local hypoxia with resultant activation of genes critical to the process [5-7]. Some of the factors 
known to be positive regulators of angiogenesis include: vascular endothelial growth factor (VEGF), acidic fibroblast growth factor (aFGF), basic fibroblast growth factor (bFGF), epidermal growth factor (EGF), TGF- $\alpha$, platelet-derived growth factor (PDGF), IL-8 and hepatocyte growth factor (HGF) [8-10]. During the early stages of angiogenesis, endothelial cells promote the focal degradation the subendothelial basement membrane, migrate through interstitial stroma towards an angiogenic stimulus, proliferate proximal to the migrating tip and organise into an anastomosing network of capillary tubes [11, 12]. These processes are controlled by soluble factors and extracellular matrix $[11,13]$ with HGF having a key role $[12,14,15]$.

Hepatocyte growth factor is a heparin-binding disulphide-linked heterodimer of $60000 \mathrm{M}_{\mathrm{r}}(\alpha)$ and $30000 \mathrm{M}_{\mathrm{r}}(\beta)$ subunits [16-19], which is secreted by cells of mesodermal origin, in particular the stromal fibroblasts and smooth muscle cells $[12,15]$, and acts on target cells through a receptor encoded by the cMET proto-oncogene [20, 21]. Endothelial cells express the c-MET receptor and respond to HGF in various in vitro assays $[12,14,22]$ with stimulation of cell motility, proliferation, migration, protease production, promotion of matrix invasion and organisation into capillary-like tubes [12, 15, 23-25]. In addition, $\mathrm{HGF}$ also stimulates the proliferation of smooth muscle cells and pericytes that participate in the formation of capillaries.

Cultured microvascular endothelial cells secrete urokinase, an enzyme associated with the development of an invasive endothelial phenotype during angiogenesis [26, 27]. Hepatocyte growth factor increases the mRNA and protein expression of both urokinase plasminogen activator (uPA) and its receptor uPAR [23, 26-29], which promotes focal degradation of the extracellular matrix proteins necessary to clear a path for the invading cells [30-33].

Like VEGF, bFGF has been shown to be a major positive regulator of angiogenesis [34]. It has been shown to induce endothelial cell proliferation, migration and angiogenesis in vitro [35]. Factors that could be involved include interstitial collagenase, uPA, UPAR, plasminogen activator inhibitor (PAI-I) and $\beta 1$ integrins [34]. Transforming growth factor- $\alpha$ (TGF- $\alpha$ ) has been found to function as a potent inducer of VEGF [36]. Transforming growth factor- $\beta$-1 (TGF $\beta-1)$ has been shown to be an indirect growth factor that modulates the number of epidermal growth factor receptors on certain cell types [37] and it has been shown to down-regulate the expression of the VEGF receptor Flk-1 [38].

Because of the known involvement of these factors in angiogenesis we determined the gene expression of HGF, its receptor c-MET, uPA and UPAR in cultured islets and islet grafts. Gene expression of vimentin, a marker for stromal fibroblasts, which can accompany angiogenesis, was also determined. In addition we also determined the pattern of gene expression of bFGF, TGF $\alpha$ and TGF $\beta-1$, and vimentin, a marker for stromal fibroblasts, in islet grafts in normal and diabetic recipients. Most notably, we found that the expression of HGF, c-MET, uPA, uPAR and vimentin was delayed in islet grafts of diabetic recipients.

\section{Materials and methods}

Animals. Islets were isolated from either male Sprague-Dawley (SD) rats (200-250 g; Taconic, Germantown, N. Y., USA) for in vitro studies or from male inbred Lewis rats (200-250 g; Harlan Sprague-Dawley, Indianapolis, Ind., USA) to be used as donors or recipients for transplantation studies. Recipients of islet grafts were either normal or diabetic rats. Lewis rats were rendered diabetic with a single dose of streptozotocin (STZ; $65 \mathrm{mg} / \mathrm{kg}$ body weight i.p.; Sigma, St. Louis, Mo., USA). Only rats with blood glucose concentrations more than $19.6 \mathrm{mmol} / \mathrm{l}$ were used as recipients of islet grafts. Blood was obtained from snipped tails of non-fasted rats (09001000 hours) twice weekly with a heparinised microcapillary tube and whole-blood glucose concentrations were measured with a portable glucose meter (One Touch II, Lifescan, Milpitas, Calif., USA). It should be noted that blood glucose values obtained with this method are about $40 \%$ lower than plasma concentrations found with standard glucose oxidase techniques [39]. Animals were kept under conventional conditions with free access to water and standard pelleted food.

Isolation and culture of islets. Islets were isolated with collagenase as described previously [40]. For culture of whole islets under normoxic and hypoxic conditions, batches of 2000-3000 islets from SD rats were cultured in $60 \times 15 \mathrm{~mm}$ non-sticky dishes with 3-5 ml of RPMI media containing a glucose concentration of $11.1 \mathrm{mmol} / \mathrm{l}$ (Cellgro, Mediatech, Herndon, Va., USA) supplemented with $10 \%$ FBS (HyClone, Logan, Utah, USA), $100 \mathrm{U} / \mathrm{ml}$ of penicillin and $100 \mu \mathrm{g} / \mathrm{ml}$ of streptomycin (Cellgro, Mediatech). These islets were initially cultured at $37^{\circ} \mathrm{C}$ in $5 \% \mathrm{CO}_{2}$ and $95 \%$ air. For studies of the effects of hypoxia, islets were cultured for the last $24 \mathrm{~h}$ of the 48 -h experiment in $1 \% \mathrm{O}_{2}$ in a triple-gas incubator (Model 480: Lab-line, Melrose Park, Ill., USA) with constant $5 \% \mathrm{CO}_{2}$ in which the oxygen was substituted with nitrogen giving hypoxic conditions of $1 \% \mathrm{O}_{2}, 5 \% \mathrm{CO}_{2}, 94 \% \mathrm{~N}_{2}$ for $24 \mathrm{~h}$ as described previously [40]. The extracts of islets analysed with PCR in this study were the same as were used for our previously reported study [40].

Islet transplantation and graft retrieval. Lewis rat islets cultured for $24 \mathrm{~h}$ were pooled, counted, sized, converted into a final islet number of 2000 islet equivalents (IE) and transplanted under the kidney capsule of normal or diabetic recipients as described in detail previously [2]. Grafts were retrieved on days $1,3,5,7$ and 14 after transplantation. Briefly, for grafts retrieved on days 1 and 3, the kidney capsule was cut with scissors around the graft and the capsule peeled back. The loosely adhering islet graft was dislodged from the surface of the kidney cortex into a Petri dish by a jet of RPMI culture media using a 10-ml syringe; the graft tissue was then handpicked and placed into an Eppendorf tube, centrifuged and suspended thereafter in Trizol solution (Life Technologies, Gaithersburg, Md., USA) for total RNA extraction. Grafts on days 5, 7 and 14 were retrieved similarly by excising the portion of capsule 
with the graft adhering to it. Using very fine forceps, the graft was removed from the capsule, cut into small fragments, placed in an Eppendorf tube and suspended in Trizol solution for extraction of total RNA [40].

$R N A$ isolation and synthesis of complementary DNA (cDNA). Total cellular RNA was prepared by a single-step method using the Trizol reagent kit (Life Technologies) as described previously [40]. The extracted RNA from isolated islets or islet grafts was resuspended in DEPC (diethyl pyrocarbonate) treated water and quantified using a UV spectrophotometer (Ultrospec 3000; Amersham Pharmacia Biotech, Piscataway, N.J., USA); between 1 and $2 \mu \mathrm{g}$ of total RNA was diluted to a final concentration of $0.2 \mu \mathrm{g} / \mu \mathrm{l}$. For cDNA synthesis, an aliquot of $500 \mathrm{ng}$ total RNA $(2.5 \mu \mathrm{l})$ was denatured at $85^{\circ} \mathrm{C}$ for $3 \mathrm{~min}$, reverse transcribed (RT) in a final volume of $25 \mu \mathrm{l}$ containing the following: $1 \times$ Superscript first-strand buffer (Gibco/BRL, Gaithersburg, Md. USA), 40 U RNasin (Promega, Madison, Wis., USA), $10 \mathrm{mmol} / \mathrm{l}$ DTT (dithiothreitol; Gibco/ $\mathrm{BRL}$ ), $50 \mathrm{ng}$ random hexamers (Gibco/BRL), $1 \mathrm{mmol} / \mathrm{l}$ deoxyribonucleoside triphosphates (dNTPs) (Gibco/BRL) and 200 U of Superscript II RNase $\mathrm{H}$ reverse transcriptase (Gibco/ BRL). Each tube was covered with a drop of mineral oil and placed in a thermal cycler, heated for $10 \mathrm{~min}$ at $25^{\circ} \mathrm{C}, 60 \mathrm{~min}$ at $42^{\circ} \mathrm{C}$ and $10 \mathrm{~min}$ at $95^{\circ} \mathrm{C}$ and brought to $4{ }^{\circ} \mathrm{C}$ after which the cDNA products were diluted with $50 \mu \mathrm{l}$ of $\mathrm{H}_{2} \mathrm{O}$ to a final concentration of $20 \mathrm{ng}$ of starting RNA per $3 \mu \mathrm{l}$ volume (20 ng RNA equivalents) [41, 42].

Semi-quantitative radioactive multiplex $R T-P C R$. Multiplex PCR reactions were done in a volume of $50 \mu \mathrm{l}$ using $3 \mu \mathrm{l}$ of cDNA (corresponding to $20 \mathrm{ng}$ RNA equivalents) in a GeneAmp PCR system 9700 Perkin Elmer thermocycler (Applied Biosystems, Foster City, Calif., USA) as template in a $47 \mu \mathrm{l}$ volume of the PCR mixture consisting of: $1 \times$ Taq buffer (Promega), $1.5 \mathrm{mmol} / \mathrm{l} \mathrm{MgCl}_{2}$ (Promega), $80 \mu \mathrm{mol} / \mathrm{l}$ cold deoxyribonucleoside triphosphates (dNTPs) (Gibco/BRL), $10 \mathrm{pmol}$ of each primer (Genosys, The Woodlands, Tex., USA), 5 U of AmpliTaq Gold DNA polymerase (Perkin Elmer, Foster City, Calif., USA) and $92.5 \times 10^{3} \mathrm{~Bq}\left(\alpha^{-32} \mathrm{P}\right)$ deoxycytidine triphosphate (dCTP) (III TBq/mmol; NEN, Boston, Mass., USA). Primers for the multiplex RT-PCR were designed with the Eugene version 2.2 software Macintosh program (Daniben Systems, Cincinnati, Ohio, USA) as described in detail previously [42]. For the c-MET/ HGF/TBP) (TATA-box-binding protein) multiplex PCR system, the oligonucleotide primers were as follows: c-MET(rat): 5 '(forward)-AAA CTC TTC CTA CCC TCC CG, 3'(reverse)-AAT CTG GCT TGC TTT GTG C (which yielded a 455-bp PCR product); HGF(rat): 5 '(forward) TCT TGA CCC TGA CAC CCC, 3 '(reverse)GTG ATT CAG CCC CAT CCG G (269-bp PCR product size) and mouse TBP as internal control: 5'(forward)-ACC CTT CAC CAA TGA CTC CTA TG, 3 '(reverse)-ATG ATG ACT GCA GCA AAT CGC (190-bp PCR product size) [42]. The thermal cycler protocol for the c-MET/HGF/TBP multiplex PCR began with a denaturing step at $94^{\circ} \mathrm{C}$ for $10 \mathrm{~min}$ (hot start PCR) to release DNA polymerase activity, then 27 cycles of $94^{\circ} \mathrm{C}$ for $1 \mathrm{~min}, 55^{\circ} \mathrm{C}$ for $1 \mathrm{~min}$ and $72^{\circ} \mathrm{C}$ for $1 \mathrm{~min}$ with a final extension step of $10 \mathrm{~min}$ at $72^{\circ} \mathrm{C}$. Oligonucleotide primers for the uPAR/uPA/TBP multiplex PCR were as follows: uPAR (rat): 5 '(forward)-AAT GGT GGC CCA GTT CTG, 3'(reverse)-AGG GTC AGG AGC AGG GAG (362bp PCR product size); uPA (rat): 5'(forward)-ACT GTG GCT GTC AGA ACG G, 3 '(reverse)-CTC TGG TTG TCG GGG TTC (298-bp PCR product size) and primers for the internal control TBP and its product size were the same as described above. The thermal cycler protocol was similar to that described above. Oligonucleotide primers for vimentin (rat) were as follows: 5'(forward)-ACA TCC ACC CGC ACC TAC, $3^{\prime}$-(reverse)CAA CTC CCT CAT CTC CTC CTC (375 bp PCR product size); $\alpha$-tubulin as internal control (rat): $5^{\prime}$ (forward) CTC GCA TCC ACT TCC CTC, 3 '(reverse)-ATG CCC TCA CCC ACG TAC (451-bp product size). Primers for the multiplex TGF $\beta-1 / \mathrm{TGF}-\alpha / \mathrm{RRPPO}$ (rat ribosomal phosphoprotein PO)were as follows: TGF $\beta$-1(rat): 5 '-(forward) GTA GCT CTT GCC ATC GGG, $3^{\prime}$-(reverse) GAA CGT CCC GTC AAC TCG (216-bp PCR product size); TGF- $\alpha$ (rat): 5 '-(forward) GAG TGA CTC ACC CGT GGC, 3 '-(reverse) CTC ACA GTG CTT GCG GAC (301-bp PCR product size) and RRPPO (rat): 5 '-(forward) TCT CCC CCT TCT CCT TCG, 3'-(reverse) CTC CGA CTC TTC CTT TGC (375-bp PCR product size). The PCR thermal cycler conditions were similar to above but with 26 cycles and annealing temperature of $59^{\circ} \mathrm{C}$ used in this case. Primers for bFGF (rat) were as follows: $5^{\prime}$-(forward) GAT CCC AAG CGG CTC TAC, 3'-(reverse) GGA CTC CAG GCG TTC AAA G (210-bp PCR product size) with mouse TBP used as an internal control and reactions were carried out at 28 cycles with an annealing temperature of $60^{\circ} \mathrm{C}$.

The gene products of interest in the multiplex PCR were co-amplified with the respective internal control gene and unincorporated $\left(\alpha-{ }^{32} \mathrm{P}\right)$ dCTP was removed from the reaction products using Micro Bio-Spin 30 gel columns (Bio-Rad Laboratories, Hercules, Calif., USA). The reaction products were then separated on a $6 \%$ polyacrylamide gel in $1 \times \mathrm{TBE}$ (TRIS-borate EDTA) buffer, dried in a gel drier and exposed overnight to a phosphoimager screen (Molecular Dynamics, Sunnyvale, Calif., USA). Incorporated $\left(\alpha-{ }^{32} \mathrm{P}\right) \mathrm{dCTP}$ in each amplimer was determined using a Strom 840 PhosphoImager with ImageQuant software (Molecular Dynamics) using the rectangle mode/average intensity subtracting background average intensity as described in detail previously [42]. Results were expressed relative to the co-amplified internal control (ratio of gene product to control gene) and thereafter expressed as a percentage of the ratio obtained with the control gene in the same RT-PCR.

To observe linear amplification of the multiplex PCR products, reaction conditions were standardised for different amounts of cDNA (ranging from 2.5 to $80 \mathrm{ng}$ RNA equivalents) and cycle number ranging from 26 to 32 cycles as shown in an example for c-MET/HGF/TBP multiplex system (Fig. 1) and as described in detail previously [42]. These experiments ensured that the ratio of PCR products to the internal control gene in the multiplex PCR reaction reflected a change in the abundance of the gene relative to the control gene. Similar experiments were conducted for all genes under investigation and optimum conditions obtained.

Expression of kidney cortex-specific NKT gene. Islet grafts retrieved from under the kidney capsule after transplantation can be contaminated with the kidney cortical tissue. Because kidney cortex also expresses HGF, c-MET, uPA, uPAR and vimentin (Fig. 2) we used a gene that is exclusively expressed in the kidney cortex so as to determine the percentage of kidney contamination in each islet graft. A gene product related to the organic ion transporter family NKT [43] was the most suitable. This product is expressed in kidney cortex but not in 24-h cultured rat islets (Fig.2). Kidney cortex also expresses the c-MET receptor but HGF was found to be expressed very faintly similar to in 24-h cultured islets (Fig. 2). High concentrations of both the UPA and its receptor UPAR were found in the kidney cortex whereas uPA expression was dominant in 24-h cultured islets (Fig. 2). Vimentin mRNA was expressed both in the kidney cortex and 24-h cultured islets (Fig. 2). The 

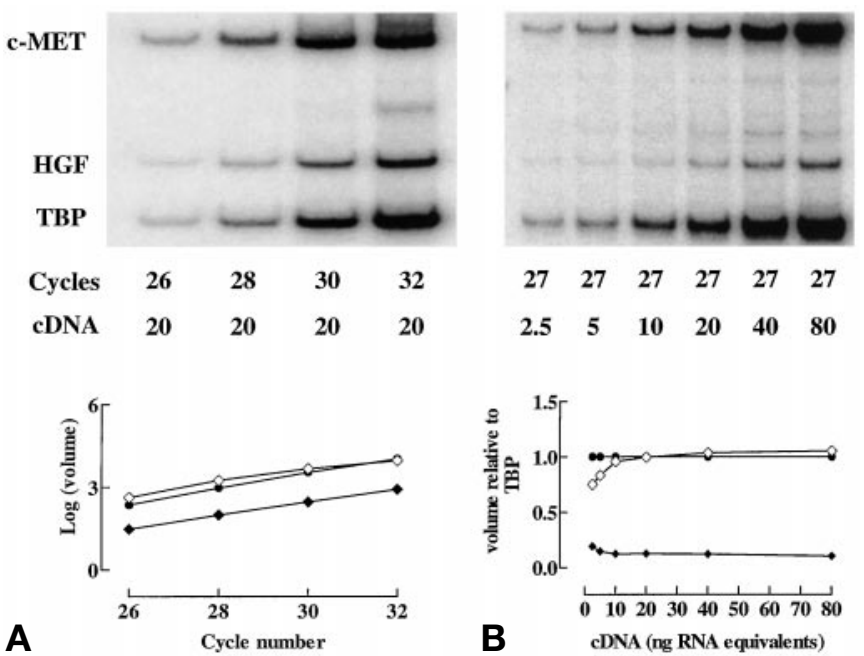

Fig. 1A, B. Validation of Semi-quantitative multiplex RTPCR for amplification for HGF $(\diamond)$, c-MET $(\diamond)$ nd TBP $(\bullet)$ as an internal control. A cDNA (3 $\mu \mathrm{l})$ corresponding to $20 \mathrm{ng}$ RNA equivalent was run with PCR mix as detailed in materials and methods in a $50 \mu \mathrm{l}$ reaction for an increasing number of cycles. Thereafter the products were separated in a $6 \%$ polyacrylamide gel and signal intensities of expected band sizes were quantified using a phosphoimager and expressed as arbitrary logarithm values of radioactivities plotted against cycle number. B Linearity of PCR amplification with cDNA ranging from 2.5 to 80 ng RNA equivalent was checked at 27 cycles, which was within the logarithmic linear range of amplification of all products. Within the wide range of starting cDNA used, the relative intensity of the signals for each product size was observed to have remained the same

contamination of islet grafts by the kidney cortical tissue was expressed as a percentage of the NKT gene expressed in $20 \mathrm{ng}$ (RNA equivalent) of kidney cortex cDNA in the same multiplex RT-PCR. This value was multiplied by the expression of the various test genes expressed in the kidney cortex and subtracted from that expressed in the islet graft. Influential contamination was only seen in a few grafts, and then almost always less than $10 \%$, with the maximum being $22 \%$. Similar corrections were carried out for the expression of TGF- $\alpha$, TGF $\beta-1$ and bFGF in islet grafts. Both TGF- $\alpha$ and TGF $\beta-1$ were well expressed in 24-h cultured rat islets whereas rat brain cDNA was used as a positive control for bFGF.

Statistical analysis. Results are expressed as means \pm SEM. For analysis, the unpaired Student's $t$ test and one-way analysis of variance (ANOVA) for multiple comparisons were used. Tukey's test was used for post-hoc analysis for multiple comparisons. Results were considered statistically significant at $p$ less than 0.05 .

\section{Results}

\section{In vitro experiments}

Expression of $H G F$ and its receptor $c-M E T m R N A$ in cultured isolated rat islets. After $24 \mathrm{~h}$ or $48 \mathrm{~h}$ of normoxic culture, there was no significant change in the

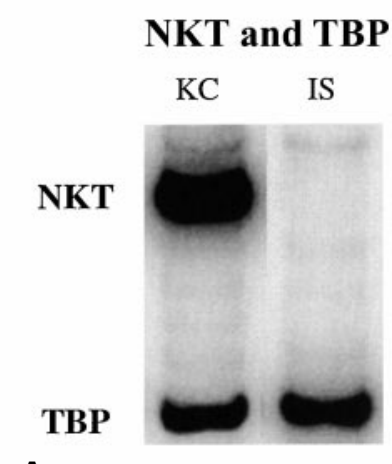

A

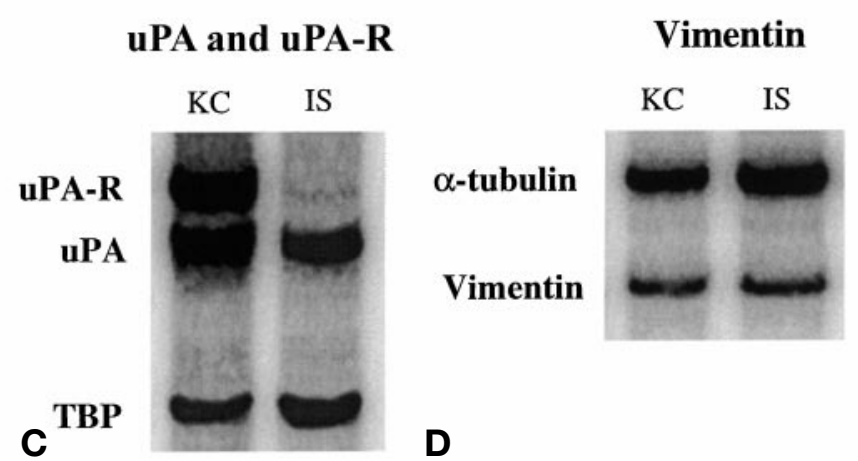

Fig. 2A-D. Expression of NKT gene in kidney cortex (KC) and in 24-h cultured rat islets (IS) as a potential test for determining the contamination of islet grafts with kidney cortical cells. NKT (A), HGF/c-MET (B), uPA/uPAR (C) and Vimentin (D) mRNA expression was determined in Lewis rat kidney cortex and in 24-h cultured islets (2000 IE) with its respective gene as an internal control. Rat liver (L) was used as a positive control for determining the expression of $\mathrm{HGF} / \mathrm{c}-\mathrm{MET}$ as shown in $\mathbf{B}$

expression of HGF mRNA compared with freshly isolated islets (Fig. 3). Subjecting islets to hypoxic culture conditions for the last $24 \mathrm{~h}$ of the 48 -h experiment, resulted, however, in a 3.4-fold increase in HGF mRNA expression compared with islets cultured for $48 \mathrm{~h}$ in normoxic culture conditions $(p<0.001)$ and a threefold increase $(p<0.001)$ compared with freshly isolated islets (Fig.3). Gene expression of c-MET mRNA was up-regulated 1.3-fold $(p<0.01)$ after $24 \mathrm{~h}$ and 1.4-fold $(p<0.001)$ after $48 \mathrm{~h}$ in normoxic culture to that of freshly isolated islets (Fig. 3). With hypoxic conditions, c-MET mRNA decreased slightly $(p<0.05)$ compared with 48 -h normoxic cultured islets but the expression was not significantly different than that found in freshly isolated islets (Fig. 3).

\section{In vivo experiments}

Gene expression of $H G F$ and its receptor c-MET $m R N A$ in islet grafts of normal and diabetic recipients. In islet grafts of normal recipients, HGF mRNA expression increased twofold in day-3 grafts 

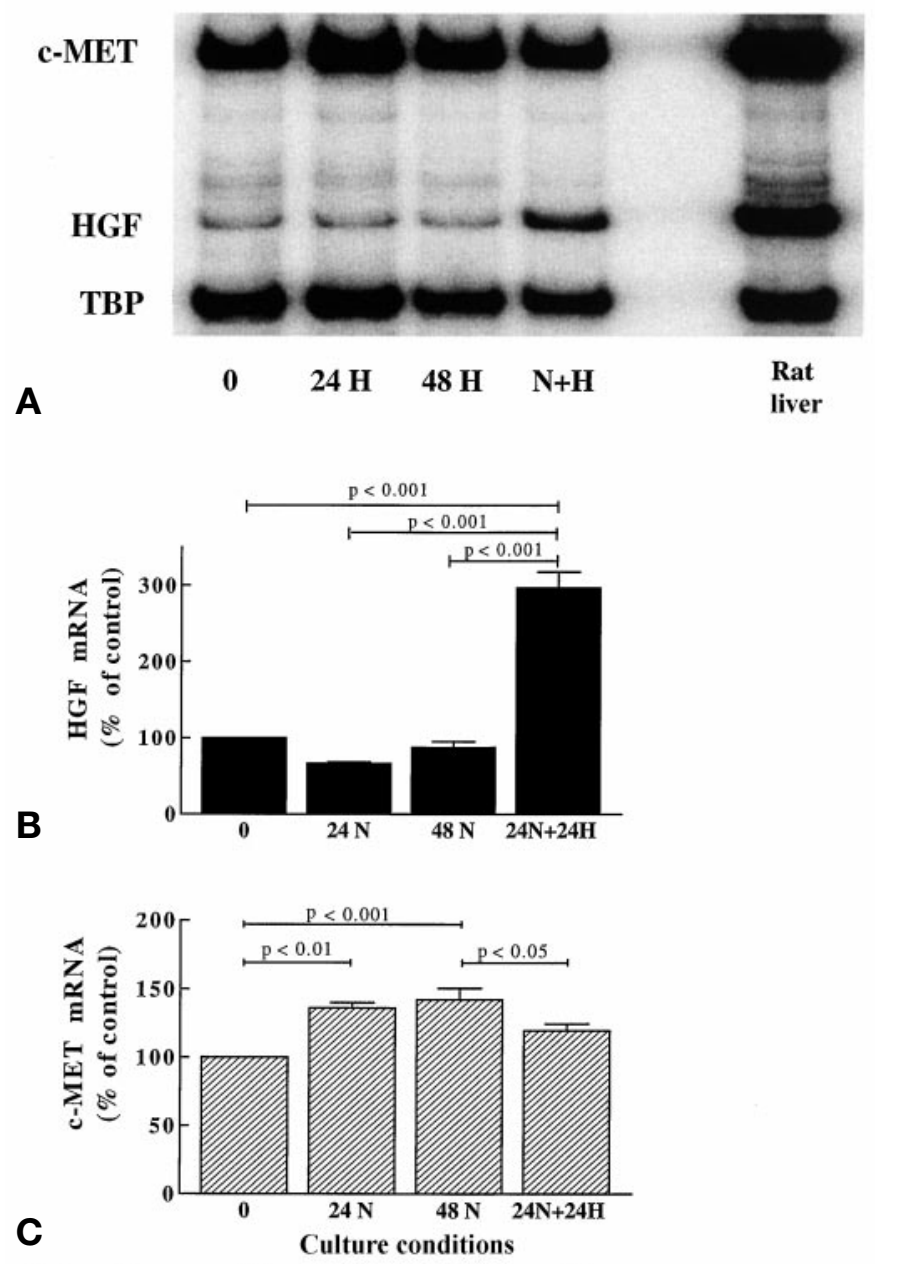

(Animals) (4) (4) (4) (4)

Fig.3 A-C. Expression of HGF and its receptor c-MET mRNA in rat islets using semiquantitative multiplex RT-PCR. Expression was determined in fresh islets (0), 24-h $(24 \mathrm{~N})$ or 48 -h $(48 \mathrm{~N})$ cultured islets in normoxic culture conditions or islets cultured in normoxic culture conditions $\left(5 \% \mathrm{CO}_{2}, 37^{\circ} \mathrm{C}\right)$ for $24 \mathrm{~h}$ followed by 24 -h culture in hypoxic $\left(1 \% \mathrm{O}_{2}, 5 \%\right.$ $\left.\mathrm{CO}_{2}, 95 \% \mathrm{~N}_{2}\right)$ conditions $(\mathrm{N}+\mathrm{H})$. Rat liver cDNA was used as a positive control as shown in (A). Bar graphs show quantification of HGF mRNA (B) and c-MET (C) expression after normalisation to the internal control gene TBP. The RNA used for these studies were the same as was used for the previously reported measurement of VEGF using northern blot analysis [40]. Results are expressed as relative normalised to mRNA expression (per cent of freshly isolated islets as control). Data were analysed by ANOVA

$(p<0.05)$ compared with that of 24 -h cultured control islets and further to a 3.8-fold increase $(p<0.001)$ in day-5 islet grafts, thereafter reaching a stable plateau of expression in 7 and 14-day grafts (Fig. 4). In the grafts of diabetic recipients, expression of HGF mRNA had a different pattern with a delay of expression, the first discernible increase being found on day 5 with a peak occurring on day 7 followed by a pronounced decrease at day 14 to $59 \%$ of the day-7 values $(p<0.001)$ (Fig. 4$)$.
The mRNA expression of c-MET in islet grafts of normal recipients decreased to $48 \%$ of 24 -h cultured control islets 1 day after transplantation (Fig. 4). Expression of c-MET mRNA decreased to $32 \%$ of control islets and then increased gradually at days 5 and 7 reaching that of the controls at day 14 (Fig. 4). In the islet grafts of diabetic recipients, c-MET mRNA expression decreased to $42 \%$ of controls $(p<0.001)$ and remained around this level until day 14 . There was no significant difference in the expression of cMET mRNA in islet grafts of diabetic recipients between days 1, 3, 5, 7 or 14 (Fig. 4).

Expression of $U P A$ and its receptor $U P A R$ in islet grafts of normal and diabetic recipients. In islet grafts of normal recipients uPA mRNA expression rapidly increased 3 days after transplantation by ninefold $(p<0.05)$ compared with 24-h cultured control islets (Fig.5). By day 14, uPA mRNA expression had increased 15 -fold $(p<0.001)$ from control values (Fig.5). In contrast, uPAR mRNA peaked in day-3 islet grafts by 4.5 -fold $(p<0.001)$ compared with controls and steadily decreased thereafter returning to starting values at day 14 (Fig. 5). In islet grafts of diabetic recipients, the pattern of expression of uPA mRNA was delayed, with an increase in expression of 5.4-fold $(p<0.01)$ found in day-5 grafts and a gradual increase thereafter reaching 9.5-fold $(p<0.001)$ in day-14 islet grafts (Fig.5). The expression of uPAR mRNA in islet grafts in diabetic recipients followed a similar pattern to that seen in normal recipients but peak expression was delayed with a 2.2-fold increase observed in day 5 islet grafts compared with controls $(p<0.001)$ followed by a decrease in control levels at day 14 (Fig. 5).

Gene expression of vimentin $m R N A$ in islet grafts of normal and diabetic recipients. In islet grafts of normal recipients, increases of vimentin expression were seen as early as the day after transplantation, followed by a climb to a peak 12 -fold increase seen in day-5 islet grafts $(p<0.001)$ compared with control islets. Thereafter, a reduction from this peak of expression was observed in day 7 and 14-islet grafts (Fig. 6). In contrast, islet grafts in diabetic recipients had a different pattern of vimentin expression (Fig. 6), with no clear increase being found on days 1 and 3 but a 4.5 -fold increase compared with control islets was seen in day-5 islet grafts $(p<0.01)$ with persistence of this elevation for the rest of the observation period.

Gene expression of bFGF, TGF- $\alpha$ and TGF $\beta-1$ in islet grafts of normal and diabetic recipients. In normal recipients, expression of bFGF in islet grafts remained similar to that of the controls at day 1 but then fell to about $50 \%$ of controls and remained at this level 

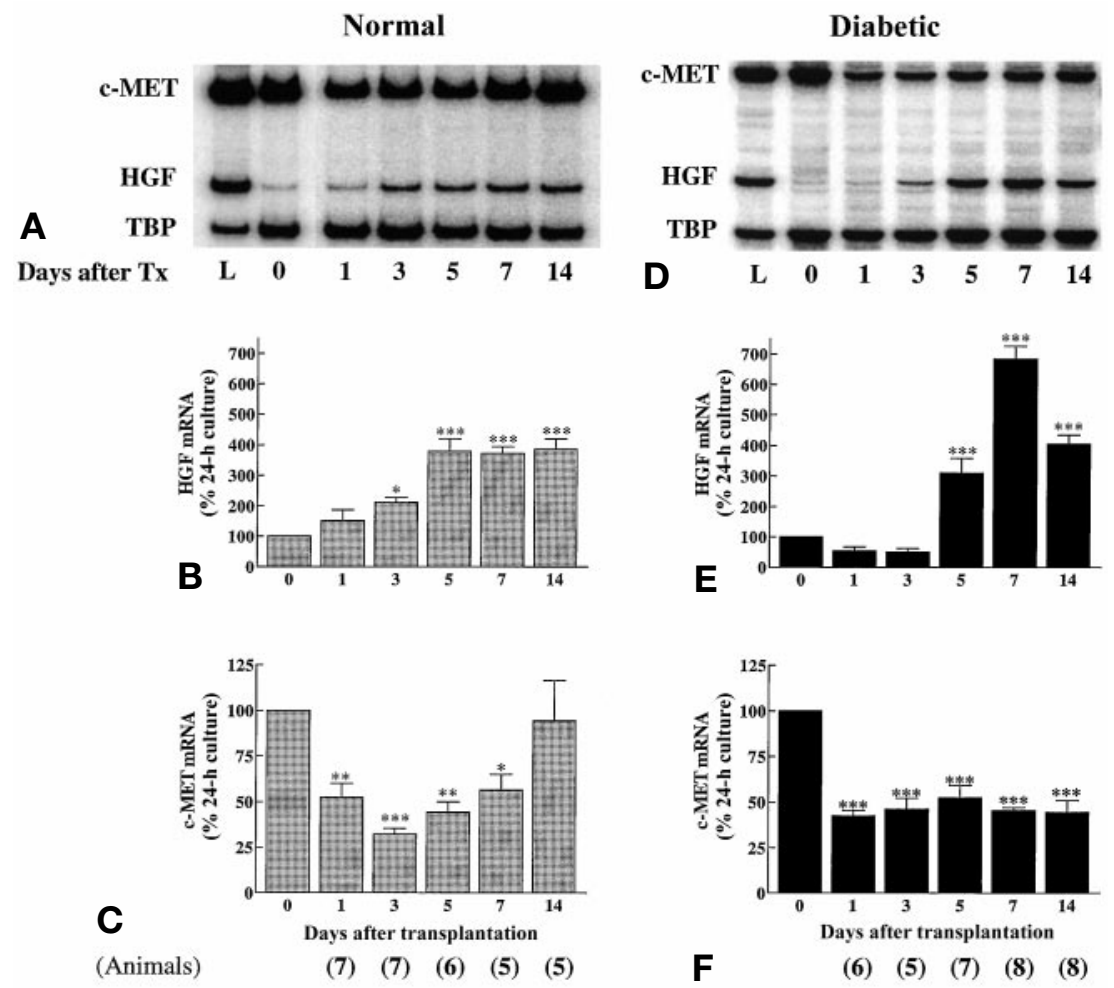

Fig. 4 A-F. Analysis of HGF and its receptor c-MET mRNA in transplanted islet grafts in normal or diabetic recipients. 2000 IE were transplanted under the kidney capsule and grafts retrieved on days $1,3,5,7$ and 14 after engraftment. Islet graft cDNA (20 ng RNA equivalent) was analysed for the expression of HGF and c-MET mRNA using TBP as an internal control gene. Representative profiles for the HGF and c-MET expression in islet grafts in normal and diabetic recipients are shown in $\mathbf{A}$ and $\mathbf{D}$. Bar graphs show quantification of expression of HGF and c-MET in normal $(\mathbf{B}, \mathbf{C})$ and in diabetic $(\mathbf{E}$, F) recipients respectively, after normalisation to the control gene TBP and expressed as a percentage of control (24-h cultured 2000 IE) \pm SEM. Data was analysed by ANOVA. Significant differences compared with 24 -h cultured islets $(0)$ alone are indicated. (* $p<0.05 ; * * p<0.01 ; * * * p<0.001)$. Rat liver cDNA (L) was used as a positive control. Tx, transplantation

throughout the observation period (Fig. 7). In diabetic recipients, expression of bFGF remained unaltered in 1 and 3-day islet grafts compared with control islets but decreased in day-5 islet grafts with this lowered expression persisting (Fig. 7). There were no significant changes found in the expression of TGF- $\alpha$ or TGF $\beta-1$ mRNA in islet grafts of normal recipients (Fig.7). In diabetic recipients expression of TGF- $\alpha$ peaked, however, in day-3 islet grafts (Fig. 7) returning thereafter to control levels whereas expression of TGF $\beta$ - 1 peaked in day- 1 islet grafts and returned to control levels (Fig. 7).

Blood glucose concentrations following transplantation. When 2000 IE were transplanted in diabetic recipients, blood glucose concentrations fell 1 day after transplantation and continued to fall until by the end of the 14-day observation the mean concentration was $10.0 \pm 0.1 \mathrm{mmol} / \mathrm{l}(n=8)$. None of the diabetic recipients achieved normoglycaemia at days $1,3,5$ or 7 after transplantation but at 14 days five out of eight recipients became normoglycaemic (blood glucose concentrations $<5.6 \mathrm{mmol} / \mathrm{l})$. At this 14-day time point, the gene expression of HGF was lower in the islet grafts of the normalised recipients than in those with persistent hyperglycaemia. In contrast, the expression of c-MET in grafts of normalised recipients was higher than in those that failed to normalise. There was no statistically significant difference in the gene expression of UPA or its receptor UPAR or of vimentin in islet grafts in either normalised or hyperglycaemic recipients.

\section{Discussion}

With measurements of gene expression in islet grafts during the 14 days after islet transplantation, the complex mechanisms of this vascularisation process are beginning to be understood. As we have shown previously (Vasir B, Jonas J-C, Steil GM et al., unpublished data), VEGF expression is increased in the grafts only during the first few days, with VEGF receptor expression, which probably originates from invading endothelial cells, being found later at about 3-5 days. In this study, we find that the expression of HGF is later than VEGF, being found at 3-5 days after transplantation, which suggests different mechanisms of induction. It could be that VEGF is being expressed in islet 

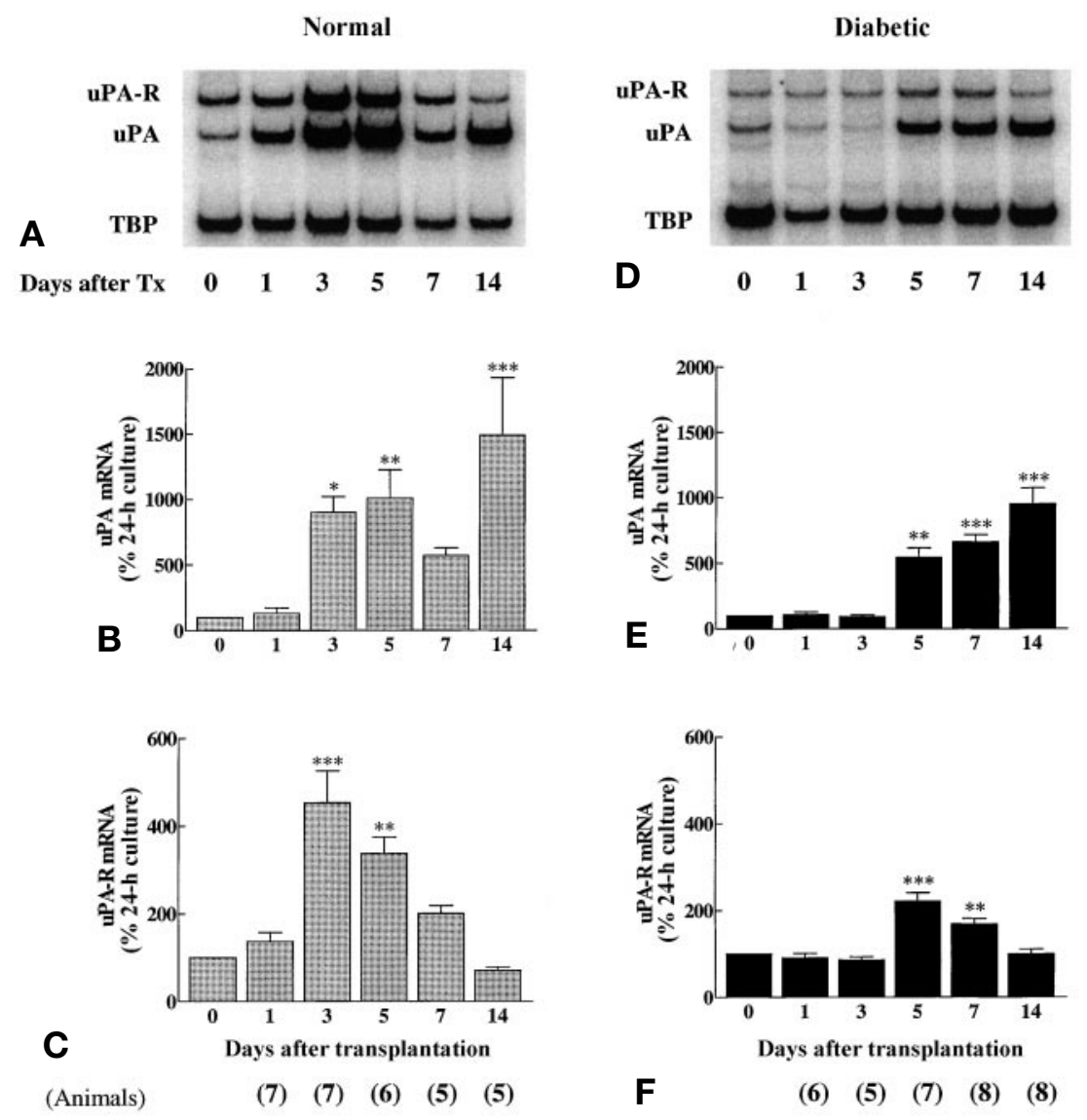

Fig.5A-F. Gene expression of uPA and UPAR mRNA in transplanted islet grafts in normal or diabetic recipients. 2000 IE were transplanted under the kidney capsule and grafts retrieved on days $1,3,5,7$ and 14 after transplantation. Islet graft cDNA (20 ng RNA equivalent) was analysed for the expression of uPA and its receptor uPAR using TBP as control gene. Representative profiles of the expression of UPA and UPAR in islet grafts in normal (A) and diabetic recipients (D) are shown. Bar graphs show quantification of expression of uPA and UPAR mRNA in normal $(\mathbf{B}, \mathbf{C})$ and in diabetic $(\mathbf{E}, \mathbf{F})$ recipients, respectively, after normalisation to the control gene TBP and expressed as a percentage of control. Data was analysed by ANOVA. Significant differences compared with 24-h cultured islets $(0)$ alone are indicated. $(* p<0.05 ; * * p<0.01$; $* * * p<0.001)$. Tx, transplantation

cells exposed to the hypoxia of early transplantation, whereas HGF, which we have shown can also be induced by hypoxia, could be coming mainly from invading fibroblasts which are known to produce $\mathrm{HGF}$ [25]. This would be consistent with the timing of the increases of vimentin expression, which presumably correlate with the appearance of fibroblasts. It is difficult to view the HGF receptors, c-METs, as being an important control mechanism but their continued expression is probably essential. The uPA expression is probably very important, as this plasmin proteolytic mechanism seems critical for catalysing extracellular

matrix/basement membrane degradation, which is a major feature of the angiogenic response [44]. Other data suggests that uPA is mitogenic for some cells, including human fibroblasts [45] and can induce the migration of endothelial cells [46], indicating the presence of actions that could be independent of its proteolytic activity. Another important role for uPA could be to cleave monomeric pro-HGF into its active heterodimeric form [47]. This process could be further enhanced because active HGF could generate more uPA. Studies in sarcoma cells and Madin-Darby canine kidney (MDCK) epithelial cells have shown that HGF/c-MET signalling increases the protein concentrations of both uPA and its cellular receptor uPAR [26, 32, 44]. Notably, another study has shown that HGF can increase the expression of both VEGF itself and its receptor Flk-1 in keratinocytes [48]. This does not fit well with the current study because VEGF expression falls as HGF expression rises but it is possible that the HGF is contributing to the later increase in Flk-1 expression.

In this study it was found that the appearance of angiogenic markers was delayed in the islet grafts of the diabetic compared with the normoglycaemic recipients. An increase of $\mathrm{HGF}$ expression was found on day 3 in the non-diabetic rats but not until day 5 in the diabetic group. The differences were even more pronounced for expression of uPA and UPAR, with big increases being found at day 3 in 
Normal

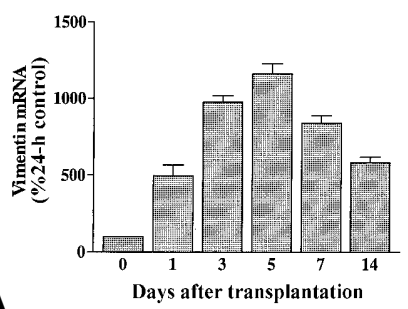

(Animals)
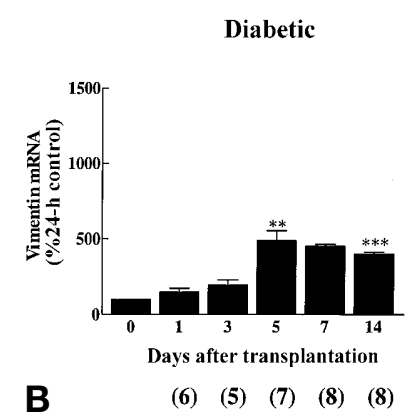

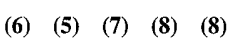

Fig. 6A, B. Analysis of vimentin mRNA in islet grafts from normal or diabetic recipients. Conditions of anlysis of vimentin were similar to that described in Fig. 5. Bar graphs show quantification of expression of vimentin mRNA in normal $(\mathbf{A})$ and diabetic (B) recipients, respectively after normalisation to $\alpha$ tubulin as the control gene and expressed as a percentage of control (0). ANOVA was used for data analysis and only significant differences between islet grafts and control islets $(0)$ are shown. $(* p<0.05 ; * * p<0.01 ; * * * p<0.001)$

Fig. 7A-F. Gene expression of bFGF, TGF- $\alpha$ and TGF $\beta-1$ in islet grafts in normal and diabetic recipients. Bar graphs show quantification of expression of bFGF, TGF- $\alpha$ and TGF $\beta$ 1 mRNA in normal $(\mathbf{A}, \mathbf{C}, \mathbf{E})$ and diabetic $(\mathbf{B}, \mathbf{D}, \mathbf{F})$ recipients, respectively after normalisation to the contol gene TBP (for bFGF) or RRPPO (for TGF- $\alpha$ and TGF $\beta-1$ ) and expressed as a percentage of control. Data was analysed by ANOVA and only significant differences compared with 24 -h cultured islets (0) alone are shown. $(* p<0.05 ; * * p<0.01$; ***p $p 0.001)$

Normal
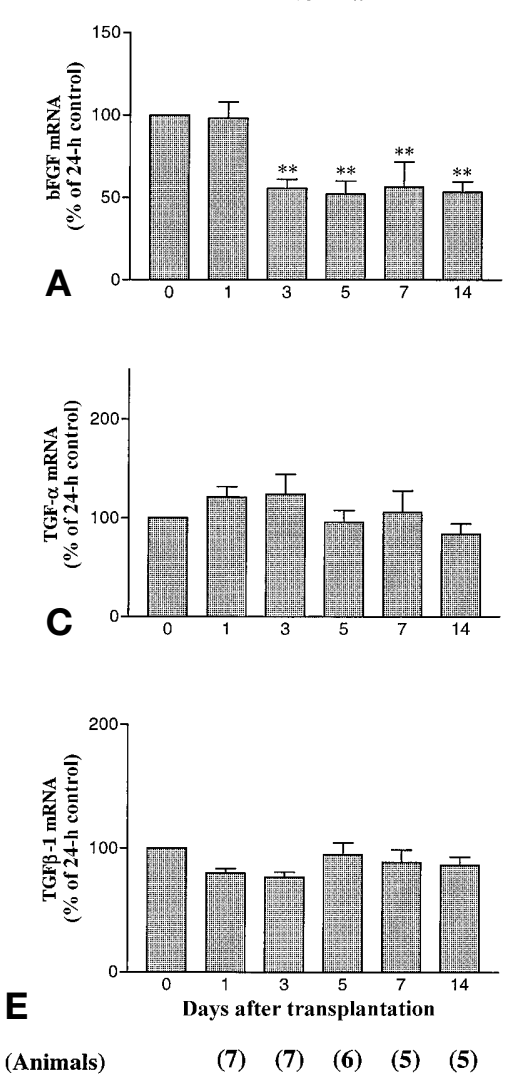

the normoglycaemic group but only at day 5 in the hyperglycaemic recipients. In an earlier study, from the same islet graft specimens, we found that gene expression of the VEGF receptors Flk-1/KDR and Flt-1, which presumably are also found in endothelial cells entering the grafts, were also found to have the same delay in timing, with increases found on day 3 in the normoglycaemic rats compared with day 5 in the diabetic group (Vasir B, Jonas J-C, Steil GM et al., unpublished data). The expression of the angiogenic peptide VEGF was also measured but VEGF should be considered more an early inducer of new blood vessels, than a marker of invading endothelial cells. In the non-diabetic grafts VEGF expression peaked the day after the transplant but in the diabetic recipients the peak was found at day 3 . Perhaps the grafts of the hyperglycaemic rats had more severe and longer lasting hypoxia leading to this pattern of VEGF expression. Vimentin, which is a marker of stromal fibroblasts, should not be considered as specific for angiogenesis as endothelial cell markers but increased vimentin expression seems to accompany the process of angiogenesis. It is therefore notable that strong vimentin expression is found in grafts as early as day 1 and 3 in the nondiabetic grafts compared with 5 days in the diabetic group, a pattern again consistent with more rapid angiogenesis in grafts maintained in a normoglycaemic environment. Wound healing has been found to be delayed in the diabetic state [49] which could in
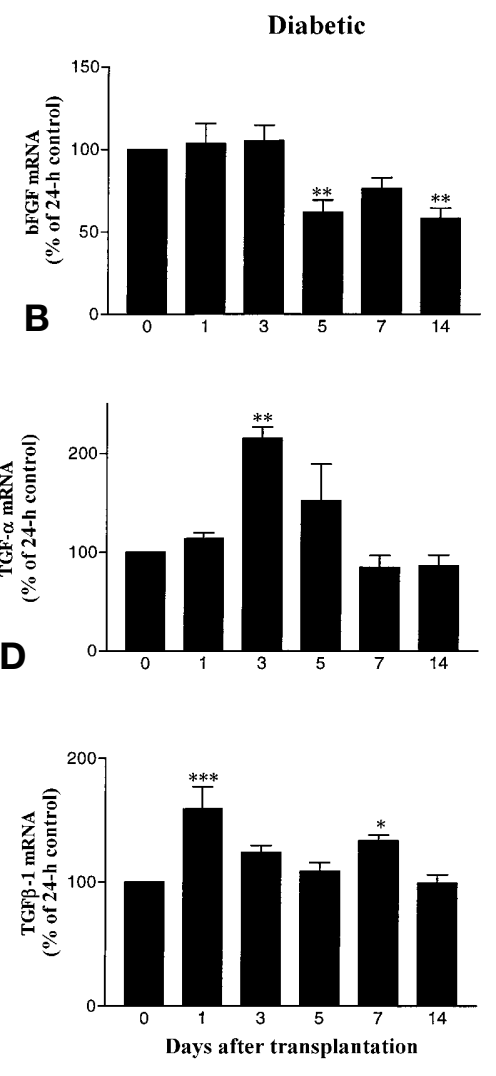

$\begin{array}{llllll}\mathbf{F} & \text { (6) } & \text { (5) } & \text { (7) } & \text { (8) } & \text { (8) }\end{array}$ 
part be due to delayed angiogenesis caused by similar mechanisms.

Although bFGF, TGF- $\alpha$ and TGF $\beta-1$ are all known to have potentially important roles in angiogenesis and could be doing so with transplanted islets, it is notable that the expression of bFGF is highest during the first few days of these experiments. Its expression then falls more slowly in the diabetic recipients, raising questions about whether angiogenesis has feedback suppression A bFGF expression. The peaks of TGF- $\alpha$ and TFG- $\beta$ in the diabetic group are notable but difficult to draw any conclusions about.

A variety of studies have found that islets transplanted into a hyperglycaemic environment do less well than when glucose concentrations are controlled or normalised $[2-4,50-52)$. To some extent this could have nothing to do with angiogenesis but instead result from more severe hypoxia of avascular clumps of islets. Even in a normoglycaemic situation, some necrosis will develop in a graft, with this occurring in the centres of islets, especially in islets greater than $200 \mu \mathrm{m}$ in diameter or any other area of the graft that is distant from capillaries [2,5]. Because oxygen consumption is known to be increased in beta cells exposed to hyperglycaemia [53], it seems highly likely that more hypoxic cell death occurs in the diabetic state. Another factor that is likely to influence oxygen delivery is the reduction of the acute inflammation caused by surgical injury. This could lead to loss of swelling, which might be helpful, but a loss of hyperaemia (the increase of blood flow in existing vessels around the graft) which could have adverse effects.

This study suggests that angiongenesis is delayed in the diabetic recipients. It must be emphasised that only gene expression was measured. More definitive analysis of this hypothesis will require assessment of angiogenesis with morphometric techniques as well as immunolocalisation and quantification of the proteins in question. The rate at which oxygen can be supplied during angiogenesis is not known but some increase in oxygen delivery might occur as early as 3-5 days. It seems possible that there are populations of beta cells that have marginal oxygen supply and increased rates of apoptosis that are rescued by early angiogenesis. In spite of the lack of precise information about these complex events, it seems likely that the delay in angiogenesis in grafts of these diabetic recipients contributes to an adverse outcome.

Acknowledgements. This work was supported by National Institutes of Health Grant DK-50657 to G. C. Weir, The Juvenile Diabetes Foundation Center for Islet Transplantation at Harvard Medical School and an important group of private donors. The core facilities for animal care were supported by National Institutes of Health Grant DK-36836 (the Diabetes Endocrinology Research Center of the Joslin Diabetes Center). We thank J. Hollister-Lock and W. Hasenkamp for laboratory assistance and Dr L.P. Aiello for providing laboratory facilities for hypoxia studies. Dr Vasir was a Fellow of the Juvenile Diabetes Foundation International.

\section{References}

1. Menger MD, Jaeger S, Walter P, Feifel G, Hammersen F, Messmer K (1989) Angiogenesis and hemodynamics of microvasculature of transplanted islets of Langerhans. Diabetes 38 [Suppl 1]: 199-201

2. Davalli AM, Scaglia L, Zangen DH, Hollister J, BonnerWeir S, Weir GC (1996) Vulnerability of islets in the immediate posttransplantation period: dynamic changes in structure and function. Diabetes 45: 1161-1167

3. Korsgren O, Jansson L, Andersson A (1989) Effects of hyperglycemia on function of isolated mouse pancreatic islets transplanted under kidney capsule. Diabetes 38: 510-515

4. Juang J-H, Bonner-Weir S, Wu Y-J, Weir GC (1995) Beneficial influence of glycemic control upon the growth and function of transplanted islets. Diabetes 43: 1334-1339

5. Dionne KE, Colton CK, Yarmush ML (1993) Effect of hypoxia on insulin secretion by isolated rat and canine islets of Langerhans. Diabetes 42: 12-21

6. Lampugnani MG, Dejana E (1997) Interendothelial junctions - structure, signalling and functional roles. Curr Opin Cell Biol 9: 674-682

7. Carlsson P-O, Liss P, Andersson A, Jansson L (1998) Measurement of oxygen tension in native and transplanted rat pancreatic islets. Diabetes 47: 1027-1032

8. Ferrara N, Davis-Smyth T (1997) The Biology of Vascular Endothelial Growth Factor. Endocr Rev 18: 4-25

9. Neufeld G, Cohen T, Gengrinovitch S, Poltorak Z (1999) Vascular Endothelial Growth Factor (VEGF) and its receptors. FASEB J 13: 9-22

10. Gleadle JM, Ebert BL, Firth JD, Ratcliffe PJ (1995) Regulation of angiogenic growth factor expression by hypoxia, transition metals and chelating agents. Am J Physiol 268: C1362-C1368

11. Folkman J (1985) Tumor angiogenesis. Adv Cancer Res 43: 175-203

12. Rosen EM, Lamszuz K, Laterra J, Polverini PJ, Rubin JS, Goldberg ID (1997) HGF/SF in angiogenesis. Ciba Found Symp 212: 215-229

13. Ingber DE, Folkman J (1989) How does extracellular matrix control capillary morphogenesis? Cell 58: 803-805

14. Bussolino F, Di Renzo MF, Ziche M et al. (1992) Hepatocyte Growth Factor is a potent angiogenic factor which stimulates endothelial cell motility and growth. J Cell Biol 119: 629-641

15. Gherardi E, Stoker M (1991) Hepatocyte growth factorscatter factor: mitogen, motogen and met. Cancer Cells 3: 227-232

16. Gherardi E, Gray J, Stoker M, Perryman M, Furlong R (1989) Purification of scatter factor, a fibroblast-derived basic protein which modulates epithelial interactions and movement. Proc Natl Acad Sci USA 86: 5844-5848

17. Weider KM, Behrens J, Vandekerckhove J, Birchmeier W (1990) Scatter factor: Molecular characteristics and effect on invasiveness of epithelial cells. J Cell Biol 111: 2097-2108

18. Miyazawa K, Tsubouchi H, Naka D et al. (1989) Molecular cloning and sequence analysis of cDNA for hepatocyte growth factor. Biochem Biophys Res Commun 163: 967-973

19. Tashiro K, Hagiya M, Nishizawa T et al. (1990) Deduced primary structure of rat hepatocyte growth factor and expression of the mRNA in rat tissues. Proc Natl Acad Sci USA 87: 3200-3204

20. Bottaro DP, Rubin JS, Faletto DL et al. (1991) Identification of the hepatocyte growth factor receptor as the c-met proto-oncogene product. Science 251: 802-804 
21. Nakamura T, Nishizawa T, Hagiya M et al. (1989) Molecular cloning and expression of human hepatocyte growth factor. Nature 342: 440-443

22. Rosen EM, Meromsky L, Setter E, Vinter DW, Goldberg ID (1990) Quantitation of cytokine-stimulated migration of endothelium and epithelium by a new assay using microcarrier beads. Exp Cell Res 186: 22-31

23. Grant DS, Kleinman HK, Goldberg ID et al. (1993) Scatter factor induces blood vessel formation in vivo. Proc Natl Acad Sci USA 90: 1937-1941

24. Tsarfaty I, Resau JH, Rulong S, Keydar I, Faletto DL, Vande Woude G (1992) The met proto-oncogene and lumen formation. Science 263: 1258-1261

25. Montesano R, Matsumoto K, Nakamura T, Orci L (1991) Identification of a fibroblast-derived epithelial morphogen as hepatocyte growth factor. Cell 67: 901-908

26. Pepper MS, Matsumoto K, Nakamura T, Orci L, Montesano R (1992) Hepatocyte growth factor increases urokinase-type plasminogen activator (u-PA) and u-PA receptor expression on Madin-Darby canine kidney epithelial cells. J Biol Chem 267: 20493-20496

27. Mandriota SJ, Seghezzi G, Vassalli J-D et al. (1995) Vascular endothelial growth factor increases urokinase receptor expression in vascular endothelial cells. J Biol Chem 270: 9709-9716

28. Rosen EM, Knesel J, Goldberg ID et al. (1994) Scatter factor modulates the metastatic phenotype of the EMT6 mouse mammary tumor. Int J Cancer 57: 706-714

29. Ellis V, Scully MF, Kakkar VV (1989) Plasminogen activation initiated by single-chain urokinase-type plasminogen activator. Potentiation by U937 monocytes. J Biol Chem 264: 2185-2188

30. Saksela O, Rifkin DB (1988) Cell-associated plasminogen activation: regulation and physiologic functions. Ann Rev Cell Biol 4: 93-126

31. Larsson L-I, Skriver L, Nielsen LS, Grondal-Hansen J, Kristensen P, Dano K (1984) Distribution of urokinasetype plasminogen activator immunoreactivity in the mouse. J Cell Biol 98: 894-903

32. Pepper MS, Sappino A-P, Stocklin R, Montesano R, Orci L, Vassalli J-D (1993) Upregulation of urokinase receptor expression on migrating endothelial cells. J Cell Biol 122: 673-684

33. Bacharach E, Itin A, Keshet E (1992) In vitro patterns of expression of urokinase and its inhibitor PA-1 suggest a concerted role in regulating physiological angiogenesis. Proc Natl Acad Sci USA 89: 10686-10690

34. Bikfalvi A, Klein S, Pintucci G, Rifkin DB (1997) Biological roles of fibroblast growth factor-2. Endocrine Reviews 18: $26-45$

35. Basilico C, Moscatelli D (1992) The FGF family of growth factors and oncogenes. Adv Cancer Res 59: 115-165

36. Gille J, Swerlick RA, Caughman SW (1997) Transforming growth factor- Biol Chem 271: 11500-11505

38. Mandriota SJ, Menoud P-A, Pepper MS (1996) Transforming growth factor $\beta 1$ down-regulators vascular endothelial growth factor receptor $2 / \mathrm{flk}-1$ expression in vascular endothelial cells. J Biol Chem 271: 11500-11505
39. Weitgasser R, Davalli AM, Capotorto JV, Finegood DT, Bonner-Weir S, Weir GC (1996) Islet transplantation in diabetic Lewis rats - A comparison of the transplantation sites kidney and spleen capsule. Acta Med Austriaca 23: 156-159

40. Vasir B, Aiello LP, Yoon K-H, Quickel RR, Bonner-Weir S, Weir GC (1998) Hypoxia induces vascular endothelial growth factor gene and protein expression in cultured rat islet cells. Diabetes 47: 1894-1903

41. Jensen J, Serup P, Karlsen C, Nielsen TF, Madsen OD (1996) mRNA profiling of rat islet tumors reveals Nkx 6.1 as a $\beta$-cell-specific homeodomain transcription factor. $\mathrm{J}$ Biol Chem 271: 18749-18758

42. Jonas J-C, Sharma A, Hasenkamp W et al. (1999) Chronic hyperglycemia triggers loss of pancreatic $\beta$ cell differentiation in an animal model of diabetes. J Biol Chem 274: 14112-14121

43. Lopez-Nieto CE, You G, Bush KT, Barros EJG, Beier DR, Nigam SK (1997) Molecular cloning and characterization of NKT, a gene product related to the organic cation transporter family that is almost exclusively expressed in the kidney. J Biol Chem 272: 6471-6478

44. Jeffers M, Rong S, Vande Woude GF (1996) Enhanced tumorigenicity and invasion-metastasis by hepatocyte growth factor/scatter factor-met signalling in human cells concomitant with induction of the urokinase proteolysis network. Mol Cell Biol 16: 1115-1125

45. De Petro G, Copeta A, Barlati S (1994) Urokinase-type and tissue-type plasminogen activators as growth factors of human fibroblasts. Exp Cell Res 213: 286-294

46. Odekon LE, Sato Y, Rifkin DB (1992) Urokinase-type plasminogen activator mediates basic fibroblast growth factor-induced bovine endothelial cell migration independent of its proteolytic activity. J Cell Physiol 150: 258-263

47. Naldini L, Tamagnone E, Vigna E et al. (1992) Extracellular proteolytic cleavage by urokinase is required for activation of hepatocyte growth factor. EMBO J 11: 4825-4833

48. Wojta J, Kaun C, Breuss JM et al. (1999) Hepatocyte growth factor increases expression of vascular endothelial growth factor and plasminogen activator inhibitor- 1 in human keratinocytes and the vascular endothelial growth factor receptor flk-1 in human endothelial cells. Lab Invest 79: $427-438$

49. Morain WD, Colen LB (1990) Wound healing in diabetes mellitus. Clin Plast Surg 17: 493-501

50. Gray DWR, Cranston D, McShane P, Morris PJ (1989) The effect of hyperglycemia on pancreatic islets transplanted into rats beneath the kidney capsule. Diabetologia 32: 663-667

51. Ar'Rajab A, Ahren B (1992) Prevention of hyperglycemia improves the long term results of islet transplantation in streptozotocin-diabetic rats. Pancreas 7: 435-442

52. Keymeulen B, Vetri M, Gorus F, Vanbrabandt B, Pipeleers DG (1993) The effect of insulin treatment on function of intraportally grafted islets in streptozotocin-diabetic rats. Transplantation 56: 60-64

53. Matschinsky FM (1996) A lesson in metabolic regulation inspired by the glucokinase glucose sensor paradigm (Banting Lecture, 1995). Diabetes 45: 223-241 